\title{
The epididymis and its role on sperm quality and male fertility
}

\author{
Ana Paula Binato de Souza, Ângela Maria Schorr-Lenz, Franciele Lucca, Ivan Cunha Bustamante-Filho ${ }^{1}$
}

Laboratório de Biotecnologia, Universidade do Vale do Taquari (Univates), Lajeado, RS, Brazil.

\begin{abstract}
The epididymis is a complex organ where spermatozoa acquire motility and ability to fertilize the egg. Epididymal maturation lasts 1 or 2 weeks and exposes the immature spermatozoa to a sequentially modified milieu, promoting intense interactions with secretions by the epididymal epithelium. Sperm surface modifications in response to interactions with epididymal secretions are key steps to achieve fertility ability. However, the precise molecular mechanisms that convert an immotile and infertile gamete into a highly motile cell capable of fusion with an oocyte are still unknown. Recent data on proteomics and transcriptomics of epididymal fluid and epididymosomes brought new ideas of the physiological roles of proteins and miRNAs in epididymal maturation in spermatozoa. This review focuses on the recent discoveries on epididymal fluid composition and its role on sperm maturation and preservation, linking to their survival and fertility potential.
\end{abstract}

Keywords: epididymis, epididymosomes, spermatozoa, proteomics, sperm maturation.

\section{Introduction}

Modern livestock production systems rely on efficient reproductive management and the continuous search for maximum efficiency has demanded new methods for animal selection and semen evaluation. Our understanding of male reproductive physiology is still expanding and the role of the epididymis on sperm maturation is considered today a key factor for male fertility. To effectively identify spermatozoa fertilizing ability, it is indispensable to determine whether the sperm cells have completed their maturation process. This complex event is tightly regulated and operated mainly by proteins secreted by the testis and epididymis, and these proteins are considered potential candidates as molecular markers. Biomarker-based semen analysis can be used not only in single ejaculate evaluation but also in both sire fertility and breeding soundness assessment (Sutovsky, 2015). The goals of this new approach are to optimize and increase the use of single sire in different livestock systems. The present review will discuss aspects of epididymal physiology and bring new information learned through genomic proteomic studies, discussing how the comprehension of sperm epididymal maturation could contribute to the development of new reproductive biotechnologies.

\section{A brief introduction to epididymal physiology}

Viable spermatozoa are produced inside several biological tubes lumina, where complex processes of cell differentiation and maturation occur. Spermatogenesis takes place in the walls of the seminiferous tubules and, after spermiation, the immature spermatozoa begin interacting with a sequence of distinct luminal environments during their transition along the excurrent ducts (Hess, 2002). Seminiferous tubules connect to the rete testis, a cuboidal epithelium forming an anastomotic network that connects to the efferent ducts, a series of 4 to 20 tubules depending on the species (Robaire et al., 2006). These tubules converge to empty into the epididymis, a single coiled duct with over $1 \mathrm{~m}$ length in the mouse, 3 $\mathrm{m}$ in the rat; and $6 \mathrm{~m}$ in the human (reviewed by Hinton et al., 2011). It is usually divided into four anatomical regions: the initial segment, head (caput), body (corpus), and tail (cauda). Each region of the epididymis is organized into lobules separated by connective tissue septa that serve not only as internal support for the organ but also as a functional separation which allows for selective expression of genes and proteins within each individual lobule (Robaire et al., 2006; Turner et al., 2003).

Both anatomical and physiological aspects of the epididymis are hurdles to overcome when studying the epididymis. Comparing proteomic or gene expression data between regions is tricky since each region behaves differently and apparently independently. In fact, the Hinton group suggested very recently that despite being formed by one single Wolffian duct, the epididymis seems to be a series of organs placed side by side (Domeniconi et al., 2016). This compartmentalized gene expression results in segment-specific protein secretions into the luminal fluid, creating sperm microenvironments where specific modifications in spermatozoa happen. The composition of the intra luminal milieu is defined by the pseudostratified epithelium composed of six cell types possessing distinct physiological functions: narrow and apical cells found in the proximal region of the epididymis and principal cells, clear cells, machophages, dentritic cells, basal cells and halo cells found throughout the organ (Breton et al., 2016; Da Silva and Barton, 2016; Kempinas and Klinefelter, 2014; Shum et al., 2014). Each cell type contributes to the establishment and regulation of a unique luminal environment for the concentration, maturation, storage, and viability of spermatozoa.

Luminal acidification is achieved by epithelial cells that have specific roles depending on their location along the epididymis (Shum et al., 2011). The importance of luminal acidification was observed in cros knockout $(\mathrm{KO})$ male mice, which are infertile and have an abnormally elevated epididymal luminal $\mathrm{pH}$ 
(Yeung et al., 2004). Similarly, a KO male mouse model for Foxi1 (a transcription factor specifically expressed in clear cells that controls the expression of proteins involved in acid secretion) presented a higher epididymal luminal $\mathrm{pH}$ compared with its wild type counterpart, being also infertile because of an inability of their spermatozoa to reach the oviduct and fertilize the egg (Blomqvist et al., 2006; Vidarsson et al., 2009). A practical observation of inhibition of luminal acidification is the exposure to environmental pollutants, such as tobacco smoke and heavy metals, which induce a reduction in male fertility (Shum et al., 2011).

Clear cells are present in caput, corpus and cauda regions of the epididymis and proximal vas deferens participating in the resorption of luminal content. Also, they contribute with the net proton secretion via the proton-pumping ATPase (V-ATPase), which is highly expressed in their apical plasma membrane (Beaulieu et al., 2005; Da Silva et al., 2007a; Da Silva et al., 2007b; Pastor-Soler et al., 2008; Shum et al., 2008). These cells are significantly more numerous in the cauda epididymis compared with the caput region, suggesting a major acidifying role in the distal region, where spermatozoa are stored (Shum et al., 2011).

Furthermore, clear cells of the human epididymis also express the V-ATPase (Da Silva et al., 2007a; Herak-Kramberger et al., 2001), indicating that the acidifying role of these cells occurs across species. The a4 promoter is under the control of the Foxil transcription factor, and several V-ATPase subunits are absent in clear cells from Foxil KO mice (Blomqvist et al., 2006; Vidarsson et al., 2009), indicating the importance of the V-ATPase in male fertility. Clear cells might contribute to the reestablishment of an acidic resting luminal $\mathrm{pH}$ following principal cell activation (Shum et al., 2011).

At alkaline luminal $\mathrm{pH}$, the V-ATPase is mainly located in well-developed apical microvilli, and at acidic $\mathrm{pH}$, it is actively recycling between sub-apical endosomes and the apical membrane. Intracellular production of bicarbonate $\left(\mathrm{HCO}_{3}^{-}\right)$is essential for the alkaline $\mathrm{pH}$-induced response and cAMP induces an apical translocation of V-ATPase identical to that induced by alkaline $\mathrm{pH}$. Alkalinization of luminal $\mathrm{pH}$, followed by an increase in intracellular $\mathrm{pH}$ in clear cells, leads to an elevation of intracellular bicarbonate concentration (Pastor-Soler et al., 2003). Bicarbonate elevation activates soluble adenylyl cyclase (sAC) and triggers cAMP production, which in turn leads to the accumulation of V-ATPase in apical microvilli. Clear cells also have the ability to respond to an increase in luminal bicarbonate concentration at constant $\mathrm{pH}$, presumably due to entry of bicarbonate across the apical membrane, and subsequent elevation in intracellular bicarbonate concentration followed by SAC activation (Pastor-Soler et al., 2003).

The epididymal epithelium cells are also responsible for water removal from the lumen with three main consequences. First, there is an increase in luminal sperm concentration from $10^{8}$ spermatozoa $/ \mathrm{mL}$ in the rete testis fluid to $10^{9}$ in the deferent duct. Second, there is a constant modulation in protein concentration, with a 10 -fold increase from the rete testis fluid and the initial segment of the epididymis ( 2 to $4 \mathrm{mg} / \mathrm{ml}$ ) to the distal caput $(50-60 \mathrm{mg} / \mathrm{ml})$ (Belleannee et al., 2011b; Dacheux et al., 2012; Fouchecourt et al., 2000).

The third consequence is related to osmolality, since the hypothesis that immature spermatozoa have a reduced ability to regulate their volume in osmotic challenging environments was considered (Cooper and Barfield, 2006). The increasing osmolality with which spermatozoa are confronted in the epididymis, if acting to reduce cell volume, should lead to an uptake of secreted permeant epididymal osmolytes during the process of regulatory volume increase. Recently, it was demonstrated that both caput and cauda sperm cells regulate volume, but cauda spermatozoa were more effective (Damm and Cooper, 2010). The osmotic stress is of great concern when developing sperm preservation media, like semen extenders routinely used in artificial insemination programs in livestock production. Despite all advances observed in sperm cryopreservation, some species like swine still face hurdles in post thaw sperm survival.

\section{The development of motility by spermatozoa during epididymal transit}

The remarkable biochemical changes in the epididymal sperm surroundings induces progressive and controlled modifications both biochemically and functionally. Motility is the most evident change in the epididymal sperm, with irregular and asymmetric flagella beating in the caput epididymis becoming symmetrical with propagation of waves on each side of the flagella, inducing forward motility of the spermatozoa when it reaches the cauda (Bork et al., 1988; Chevrier and Dacheux, 1992; Dacheux and Dacheux, 2014). However, such motility is only observed in vitro when epididymal sperm have been washed free of epididymal fluids and extended in a proper artificial medium. In vivo, weak beating flagella can be seen in the rete testis and efferent duct fluids, but after the increase in sperm concentration in the epididymal fluid, most of the spermatozoa maintain quiescent motility whatever its location in the epididymis (Dacheux and Dacheux, 2014).

The sperm flagellum machinery at the output of the testis is molecularly functional but inactivated in vivo, however the precise mechanism of activation of sperm motility in the epididymis is still unclear. This cell function is dependent on the intracellular cAMP generated by adenylyl cyclase, and on subsequent successive protein phosphorylations including protein kinase A, A-kinase anchor proteins and many other phosphorylated proteins (Esseltine and Scott, 2013; Perino et al., 2012; Turner, 2006).

Throughout the epididymal lumen, the sperm's intracellular cAMP level increases from the corpus to the cauda (Dacheux and Paquignon, 1980; Hoskins et al., 1974; Pariset et al., 1985), simultaneously with metabolic capacity and ATP production (Inskeep and 
Hammerstedt, 1982). In addition, $\left[\mathrm{HCO}_{3}^{-}\right]$and $\left[\mathrm{Ca}^{2+}\right]$ are key factors of the luminal epididymal fluid, which could directly control intracellular cAMP concentrations in the epididymal spermatozoa and consequently activate protein phosphorylation and motility (Xia et al., 2007). Calcium combined with bicarbonate ions is able to accelerate the flagellar beating of mature sperm in vitro, changing to symmetrical flagellar wave propagation, directly associated with the level of internal $\left[\mathrm{Ca}^{2+}\right]$ (Carlson et al., 2007; Lindemann et al., 1991). Instead, the removal of $\mathrm{Ca}^{2+}$ prevents this speeding up of flagellar beating (Carlson et al., 2003). Therefore, the low concentration of luminal and intracellular sperm $\left[\mathrm{Ca}^{2+}\right]$ found in the terminal part of the epididymis contributes to maintaining mature sperm motility quiescent (Dacheux and Dacheux, 2014). These findings point out that the control of the intracellular cAMP of spermatozoa and, consequently, protein phosphorylation is the key to understand the progressive acquisition of motility during epididymal transit. Determining the precise way sperm acquire motility in the epididymis could result in the development of better semen processing protocols in cases of male infertility.

\section{Regulation of secretory activity in the epididymis}

While half of the epididymal proteins are under positive or negative control by androgens, other proteins (43\%) are modulated by local factors or are not influenced despite the physiological conditions (Syntin et al., 1999). The influence of lumicrine factors on the epididymis has been investigated after efferent duct ligation (EDL), avoiding testicular factors from entering the epididymis (Robaire et al., 2006). As a consequence, several phenomena were observed like epididymal gene expression changes (Hermo et al., 2000; Hinton et al., 1998; Lan et al., 1998), decreased protein synthesis and secretion (Holland et al., 1992) and apoptosis of epithelial cells of the initial segment (Abe and Takano, 1989; Fan and Robaire, 1998; Nicander et al., 1983). After EDL, secretion in the proximal caput is the most highly affected region with a 50\% decrease in the specific proteins found in this region, such as RNaseTrain A (Dacheux et al., 2005).

Testicular factors play a role in the control of protein secretion in the first part of the epididymis. Specific proteins of the epididymal caput, such as glutathione peroxidase (GPX) and hexosaminidase (HEX), are positively regulated by testosterone. In the distal caput and corpus, lactoferrin, Niemann-Pick type $\mathrm{C}$ protein also called Cholesterol Transfer Protein or HE1 (NCP2/CTP/HE1) and E-RABP are also stimulated by androgens, whereas clusterin is inhibited (Dacheux et al., 2005). Indeed, several genes have been shown to depend on testicular factors with diverse bioactivities such as gamma-glutamyl transpeptidase (Palladino and Hinton, 1994a; Palladino and Hinton, 1994b), GPX (Rigaudiere et al., 1992; Vernet et al., 1997), 5-alpha-reductase (Viger and Robaire, 1996), and ADAM7 (Cornwall and Hsia, 1997).

Also, the epididymal physiology is strongly regulated by steroid hormones. Several papers described the influence of orchiectomy and EDL in the epididymis, with dramatic changes in morphology and function (Brooks, 1976; Ezer and Robaire, 2003; Fawcett and Hoffer, 1979; Turner et al., 2007a; Turner et al., 2007b). Therefore, there is a proven dependence on testicular and circulating factors for proper epididymal function (Belleannee et al., 2011a). Testosterone produced by Leydig cells affects metabolism, ion transport, synthesis and secretion of epididymal proteins and sperm maturation, transport and storage (Bilinska et al., 2006). In rabbits, testosterone leaves the testis through the efferent ducts and is incorporated into principal cells of the epididymis by endocytosis of the complex testosterone-androgen binding protein (ABP) (Danzo et al., 1977). There, it can be quickly metabolized to dihydrotestosterone (DHT) by 5-alpha reductase, and to estradiol by aromatase P450 (Robaire and Hamzeh, 2011; Robaire et al., 2006).

In epididymal cell lines androgenic regulation of gene expression involves the androgen dependent signaling pathways MEK, ERK $1 / 2$ and CREB, (Hamzeh and Robaire, 2011). Additionally, formation of an androgen-androgen receptor (AR) complex regulates transcription of androgen response elements (AREs) containing-genes (Heinlein and Chang, 2002a; Heinlein and Chang, 2002b; Janne et al., 2000). Interestingly, like androgens, estrogens are present at a very high concentration in the testis and are generated from the aromatization of testosterone both in Leydig cells (Hess et al., 2001a; Hess et al., 2001b) and in epididymal spermatozoa (Hess et al., 1995; Joseph et al., 2011). Estrogens' biological effects are induced via interaction with ESR1 or ESR2 nuclear receptors and subsequent recognition of estrogen response elements (EREs) located in the promoters of target genes (Joseph et al., 2011).

\section{Role of epididymal proteome in sperm maturation}

The epididymal fluid is described as the most sequentially modified milieu of the body. And the most important change in this luminal fluid is induced by water reabsorption (Dacheux and Dacheux, 2014). Together with secretory activities of the tubular epithelium, these changes modulates metabolic pathways, such as second messenger and intracellular protein phosphorylation levels, energy metabolism, plasma membrane transport (Dacheux et al., 1989; Ecroyd et al., 2004; Jones et al., 2007; Saez et al., 2011; Voglmayr et al., 1985) (for review, refer to (Cornwall, 2009; Robaire et al., 2006)). This "passive" maturation is necessary because spermatozoa have no or very low capacity to synthesize new components, owing to their condensed DNA (Belleannee et al., 2012b).

The outstanding contributions of the Dacheux group to the characterization of seminal plasma and epididymal fluids of different species - including monotremes (Nixon et al., 2011), opened new roads for the study of male reproductive physiology. Hundreds of epididymal proteins have already been identified from the epididymal fluid of different species. For all these 
epididymal fluids characterized, so far no more than twenty proteins are present in high concentrations, representing 80 to $90 \%$ of the total luminal proteins (Dacheux and Dacheux, 2014). Several of these proteins are common to different species such as lactoferrin, lipocalin 5, clusterin, glutathione peroxidase 5, prostaglandin D2 synthase, transferrin, Niemann-Pick disease, type $\mathrm{C} 2$, phosphoethanolamine binding protein 4, beta-N-acetyl-hexosaminidase, glutathione $\mathrm{S}$ transferase, gelsolin, actin, beta galactosidase (Dacheux and Dacheux, 2014). Specifically in man, $77 \%$ of the total luminal proteins are represented by albumin (43.8\%), clusterin (7.6\%), NCP2/CTP/HE1 (6\%), lactoferrin $(5.9 \%)$, extracellular matrix protein $(3.2 \%)$, $\alpha 1$-antitrypsin (2.7\%), prostaglandin D2 synthase $(2.2 \%)$, transferrin $(1.3 \%)$, and actin binding protein $(1.2 \%)$ (Dacheux et al., 2006).

Significant variations among species both in concentration and in regionalization of epididymal proteins were described. For example, lactoferrin, mannosidase, prostaglandin D2 synthase, and albumin are present in high concentrations in the stallion, boar, ram, and human, respectively, but glutathione peroxidase and prostaglandin D2 synthase are virtually absent from the human and boar, respectively (Guyonnet et al., 2011).

Souza and coworkers detected $113 \pm 7$ spots per gel of cauda epididymal fluid from rams by means of 2D SDS-PAGE analysis (Souza et al., 2012). The most abundant proteins in these gels appeared as albumin and transferrin. These proteins corresponded to $27.3 \%$ of all spot intensities and were present as trains of multiple isoforms. Such molecular heterogeneity is linked to post translational modifications (mostly different degrees of glycosylation), which occur in the secretory cells and that induce the secretion of series of isoforms of the same protein (Dacheux et al., 2005). Other proteins identified include clusterin, alpha-1-antitrypsin, prostaglandin D synthase, alpha-2-HS glycoprotein and actin.

In bulls, Moura et al. identified $114 \pm 3$ spots in the cauda epididymal fluid protein maps and the most abundant proteins were albumin $(21.1 \%)$, epididymal secretory protein E1 (10.5\%), prostaglandin D-synthase $(7.6 \%)$ and gelsolin (6\%) (Moura et al., 2010). Many proteins appeared in the CEF map as groups of isoforms, such as clusterin (11 spots), transferrin (6 spots), $\mathrm{N}$-acetyl- $\beta$-glucosaminidase ( 6 spots), cauxin ( 7 spots), prostaglandin D-synthase (4 spots), gelsolin (3 spots) and glutathione peroxidase (2 spots). Other proteins identified were acidic seminal fluid protein (aSFP), aldehyde reductase, $\alpha$-L-fucosidase, $\alpha-1-\beta$ glycoprotein, apolipoprotein A-1, $\beta$ actin, calmodulin, cathepsin $\mathrm{D}$, cystatin $\mathrm{E} / \mathrm{M}, \alpha-1$-antitrypsin, enolase, galectin 3- binding protein, leucine amino-peptidase and a 49-kDa nucleobindin.

In boars, the proteomic profile of the epididymal fluid also showed a very high polymorphism, both in molecular mass and $\mathrm{p} I$, as principal characteristic of the proteins secreted in the lumen. A total of 125 epididymal proteins were identified by mass spectrometry covering 187 spots
(Syntin et al., 1996). The number of isoforms secreted for a given protein varied according to the epididymal region. Additionally, post-secretory modifications such as partial proteolysis and deglycosylation may occur, thus, influencing the number of isoforms present in the lumen for a given protein as it transits along the epididymis. The secretory activity of the caput region is 6- 8 times greater than that of the caudal region (Dacheux et al., 2005). Protein secretion in the caput, corpus and cauda, thus, represents 83,16 and $1 \%$ of the overall secretion of the epididymis, respectively. The maximum secretory activity corresponds to the maximum concentration of sperm in the fluid and a minimum volume surrounding them. The most abundant proteins are RNase-Train A, GPX, NCP2/CTP/HE1, retinoic acid binding protein (E-RABP), mannosidase, hexoaminidase, clusterin, cathepsin L, lactoferrin. Only one protein is specific for the distal corpus, train $\mathrm{H}$ (36$40 \mathrm{kDa}$ ), while two minor proteins appear in the cauda (Dacheux et al., 2005; Syntin et al., 1996).

In the stallion, the protein concentration of 35 $\mathrm{mg} / \mathrm{ml}$ in the proximal caput is around 5 times higher than in rete testis fluid (Fouchécourt et al., 2000). The concentration increases to a maximum value of $60-80$ $\mathrm{mg} / \mathrm{ml}$ in the distal caput, and then decreases progressively toward the corpus and cauda to reach 20 $30 \mathrm{mg} / \mathrm{ml}$. A total of 324 different spots distributed throughout the epididymis were detected, corresponding to 201 isolated spots or trains of different proteins. The 5 major polymorphic proteins secreted by testicular tissue were an isoform of clusterin, an isoform of prostaglandin $\mathrm{D}$-synthase (30 kDa, pI 5.5-6), train $\mathrm{T} 1$ (67-80 kDa, pI 4-6.2), train T2 (94 kDa, pI 6.5), and train T3 (43 kDa, pI 6.5-7.8). Trains T1, T2, and T3 were specific to the testis. The caput was the most active region, accounting for $73 \%$ of the total epididymal secretion. The corpus was the next most active, secreting $20.5 \%$, followed by the cauda, $6.5 \%$. Lactoferrin and clusterin were the most abundant proteins, making up $41.2 \%$ and $24.8 \%$ of the total epididymal secretion, respectively. Procathepsin D (5.2\%), CTP/HE1 (3\%), hexosaminidase (2.9\%), prostaglandin D-synthase (2.3\%), and GPX (1.4\%) were the other major compounds secreted (Fouchécourt et al., 2000).

After secretion, these proteins display different fates, such as accumulation of or changes in their modifications that give rise to many different isoforms. Not all of these major secreted proteins remain in the fluid: in the boar, RNAse 10 is present in the anterior caput fluid but is reabsorbed in the next zones, and almost no protein can be found distal to the caput region (Castella et al., 2004). The same pattern was observed for chaperones belonging to the protein disulfide isomerase (PDI) family in sperm and epididymal fluid from boars (Schorr-Lenz et al., 2016).

This resorptive activity is mostly visible in the vas deferens and the proximal caput, where the fluid is mainly composed of testicular fluid and a few epididymal secreted proteins (Guyonnet et al., 2011). Most of the proteins originating from the testis, such as albumin, transferrin, and testicular clusterin, are rapidly 
reabsorbed in the efferent ducts, and generally almost all testicular proteins are removed from the fluid before the posterior part of the epididymis (Clulow et al., 1994; Dacheux et al., 2009; Dacheux et al., 2003; Syntin et al., 1996; Veeramachaneni and Amann, 1991). However, some variations among species occur, such as in humans, for which albumin and transferrin remain in large quantities throughout the duct (Dacheux et al., 2006).

Today, proteomic methods became more powerful using shotgun mass spectrometer approaches, with higher sensitivity and throughput results (Amaral et al., 2013; Amaral et al., 2014). Using advanced mass spectrometry and a proteomics platform, Wang et al. (Wang et al., 2013) identified 4675 proteins from human sperm, which is about 4-fold greater than the previously estimated number, demonstrating the unexpected complexity of the human sperm protein composition. With such a large-scale sperm proteome, it is possible to analyze functional pathways in sperm, not only helping the study of sperm function, but also in the development of contraceptive drugs. Annotation of drug targets showed that 500 human sperm proteins are known targets (Wang et al., 2013). The list of sperm proteins can be a rich resource for the development contraceptive drugs. For example, the identified Angiotensin-converting enzyme (ACE) has been shown to be important for male fertility in mice (Krege et al., 1995). Thus, its inhibitors, such as enalapril and quinapril and other 13 different drugs, could be tested as part of new human contraceptive approaches (Wang et al., 2013).

Proteomic research of both sperm and seminal plasma opened doors for a better understanding of the role of specific proteins in semen quality and fertility. Despite the association of several proteins with semen traits (for example the characterization of bovine osteopontin as a seminal plasma fertility-associated protein (Cancel et al., 1997)), suggested molecular markers for sperm quality did not become part of routine ejaculate examination and semen processing. It is accepted that the current methods used in sperm quality assessment are unsatisfactory to correctly predict sperm fertility potential. Also, they do not provide enough information for diagnosing and overcoming possible clinical infertility situations (Payan-Carreira et al., 2013). Therefore, there is a significant window of opportunity for the biotechnological use of semen protein markers to select for or to improve semen quality and fertility in both in human and animal reproduction.

\section{The crosstalk between epithelial cells and spermatozoa during epididymal transit}

The acquisition of intraluminal epididymal proteins by transiting spermatozoa occurs by means of hydrophobic interactions (Cooper, 1998). Some sperm proteins acquired during maturation do not behave as coating proteins when sperm cells are experimentally submitted to different biophysical treatments (Thimon et al., 2008b). Some of them behave as integral membrane proteins,

including GPI (glycosylphosphatidylinositol) anchored-proteins (Kirchhoff et al., 1996; Legare et al., 1999), while others are integrated inside sperm cell compartments during the maturational process, probably involved in sperm motility (Eickhoff et al., 2004; Eickhoff et al., 2006; Eickhoff et al., 2001).

The incorporation of epididymal proteins by spermatozoa cannot be explained by the classical secretory pathway (Cooper, 1998; Sullivan et al., 2007; Thimon et al., 2008b). Many sperm proteins acquired during the epididymal transit behave as integral membrane proteins when cells are treated with different extraction procedures. Apocrine secretion and exosomes are the main mechanism of transfer of epididymalsecreted proteins to the sperm plasma membrane (Sullivan et al., 2005). The epididymosomes are blebs released from the apical pole of principal cells, and their contents appear to be segregated; only free ribosomes, endoplasmic reticulum cisternae, and small membrane vesicles are visualized (Hermo and Jacks, 2002; Rejraji et al., 2006). The presence of these $20 \mathrm{~nm}$ diameter vesicles in the apical cytoplasm of cells forming blebs, as well as in the intraluminal compartment, suggests that they are liberated in the epididymal lumen once blebs detach from principal cells (Sullivan and Saez, 2013). The cholesterol:phospholipids ratio of these vesicles can be as high as 2 , and sphingomyelin is the major phospholipid constituent (Sullivan et al., 2005). Epididymosomes in the epididymal fluid have been reported in rat (Eickhoff et al., 2001; Fornes et al., 1995), bovine (Fraile et al., 1996; Frenette et al., 2003; Sutovsky et al., 2001), mouse (Rejraji et al., 2002), horse (Sostaric et al., 2008) and man (Thimon et al., 2008b).

The protein composition of epididymosomes is complex and varied along the epididymis. In rams (Gatti et al., 2004; Gatti et al., 2005) and bulls (Frenette et al., 2003; Frenette et al., 2002), epididymosome protein concentration differs from fluids or spermatozoa collected in the same segment of the epididymis. The proteome of epididymosomes collected in the caput and cauda epididymis in bovine is composed of 555 and 438 proteins respectively, being that 231 proteins are common to both types of epididymosomes (Girouard et al., 2011). Proteins proposed to be involved in spermegg interaction and motility, as well as proteins involved in remodeling of sperm components or potentially involved in sperm protection and elimination, were shown to be associated with epididymosomes (Sullivan and Saez, 2013). The proteome of cauda epididymosomes collected from the vas deferens during surgical vasectomy reversal in men showed that epididymosomes transit along the epididymis in humans and that vesicles collected distally represent a mixed population of vesicles secreted all along the epididymis (Thimon et al., 2008a; Thimon et al., 2008b).

The fusogenic properties of bovine epididymosomes with spermatozoa were investigated by Schwarz et al. who observed that spermatozoa isolated from the epididymal caput showed a higher fusion rate 
(both $\mathrm{pH}$ and time dependent) than those taken from the cauda (Schwarz et al., 2013). Also, the lipid and protein content in spermatozoa changed during epididymal transit and after in vitro fusion with epididymosomes. The authors also demonstrated the transfer of epididymis-derived PMCA4 to spermatozoa via epididymosomes.

In a recent paper from the Sullivan group, the study of epididymal sperm binding protein 1 (ELSPBP1) in dead spermatozoa shed some light in how epididymosomes transfer proteins to sperm. To date, ELSPBP1 function remains unclear but its sequence similarity with binder of sperm proteins (BSPs) suggests a role on modulation of phospholipids and cholesterol in sperm membrane (Ekhlasi-Hundrieser et al., 2007; Manjunath et al., 2007; Manjunath and Thérien, 2002). With an elegant approach, D'Amours and coworkers showed that ELSPBP1 is secreted by principal cells in association with epididymosomes, which specifically transfer ELSPBP1 only to spermatozoa already dead before incubation (D'Amours et al., 2012). This receptivity was enhanced by the presence of zinc in the incubation medium. As a result, a subpopulation is formed suggesting an underlying mechanism involved, in which ELSPBP1 could be a tag for the recognition of dead spermatozoa during epididymal transit.

In the last decade, small non-coding RNAs such as microRNAs (miRNAs) have gained attention as critical regulators of gene expression in several biological processes, including differentiation of the epididymal epithelium and acquisition of male fertility (Bjorkgren et al., 2012; Hawkins et al., 2011; Papaioannou and Nef, 2010). Consisting of about 22 nucleotides, miRNAs regulate posttranscriptional gene expression by targeting mRNAs for cleavage or translational repression (Bartel, 2009). Distinct miRNA signatures in the caput, corpus and cauda of human epididymis were found to correlate with epididymal gene expression pattern (Belleannee et al., 2012a).

The Sullivan group was the first to report the ability of epididymosomes to transport miRNAs, extending the current knowledge with regards to the role of epididymosomes in the transfer of proteins to maturing spermatozoa. In a bovine model, small RNAs were found to be threefold more abundant in epididymosomes from the proximal region compared to those in the distal region (Belleannee et al., 2013). Overall, 1645 miRNA sequences from 74 different species and 82 bovine miRNA sequences were detected with strong signal intensity in epididymosomes. Among these, 178 miRNAs were differentially detected between caput and cauda epididymosomes, including 92 miRNAs enriched in caput epididymosomes and 86 enriched in cauda epididymosomes. miRNA populations from epididymosomes did not mirror the miRNA profiles of their surrounding epithelium, suggesting that instead of being passively released by epididymal epithelial cells, subpopulations of epididymal miRNAs may employ selective and distinct biogenesis and secretion pathways that are regulated in a region-specific manner along the epididymis.
Similarly, other studies proposed that the miRNA content of extracellular vesicles does not simply imitate the miRNA repertoire of the cells of origin (GuduricFuchs et al., 2012; Mittelbrunn et al., 2011).

\section{Concluding remarks}

During the first one or two weeks of posttesticular life, spermatozoa is incarcerated in a long and highly coiled biological tube, nevertheless experiencing different environments until ejaculation. These subtle sequential changes in the luminal milieu are a result of regionalized specialization of the epididymal epithelium. Coordinated secretions and endocytosis lead to an intense modification of the epididymal fluid protein profile, exposing the gametes to factors that will modulate sperm physiology. Moreover, apocrine secretions of principal cells produce epididymosomes that deliver target proteins, miRNAs and lipids to spermatozoa, a fundamental event for gamete recognition and fusion. Research on the molecular processes driving the vesicle-dependent maturation of spermatozoa, as well as several other luminal components, will increase the understanding of sperm maturation in the epididymis, opening doors for the discovery of new markers for semen quality and fertility.

\section{Acknowledgements}

We thank CNPq, CAPES, FAPERGS and FUVATES for funding projects in the laboratory. The authors apologize to the many scientists whose research could not be cited because of space considerations.

\section{References}

Abe K, Takano H. 1989. Cytological response of the principal cells in the initial segment of the epididymal duct to efferent duct cutting in mice. Arch Histol Cytol, 52:321-326.

Amaral A, Castillo J, Estanyol JM, Ballesca JL, Ramalho-Santos J, Oliva R. 2013. Human sperm tail proteome suggests new endogenous metabolic pathways. Mol Cell Proteomics, 12:330-342.

Amaral A, Castillo J, Ramalho-Santos J, Oliva R. 2014. The combined human sperm proteome: cellular pathways and implications for basic and clinical science. Hum Reprod Update, 20:40-62.

Bartel DP. 2009. MicroRNAs: target recognition and regulatory functions. Cell, 136:215-233.

Beaulieu V, Da Silva N, Pastor-Soler N, Brown CR, Smith PJ, Brown D, Breton S. 2005. Modulation of the actin cytoskeleton via gelsolin regulates vacuolar H+-ATPase recycling. J Biol Chem, 280:8452-8463.

Belleannee C, Belghazi M, Labas V, Teixeira-Gomes AP, Gatti JL, Dacheux JL, Dacheux F. 2011a. Purification and identification of sperm surface proteins and changes during epididymal maturation. Proteomics, 11:1952-1964.

Belleannee C, Calvo E, Caballero J, Sullivan R. 2013. Epididymosomes convey different repertoires of 
microRNAs throughout the bovine epididymis. Biol Reprod, 89:30.

Belleannee C, Calvo E, Thimon V, Cyr DG, Legare C, Garneau L, Sullivan R. 2012a. Role of microRNAs in controlling gene expression in different segments of the human epididymis. PloS one, 7:e34996.

Belleannee C, Labas V, Teixeira-Gomes AP, Gatti JL, Dacheux JL, Dacheux F. 2011b. Identification of luminal and secreted proteins in bull epididymis. $J$ Proteomics, 74:59-78.

Belleannee C, Thimon V, Sullivan R. 2012b. Regionspecific gene expression in the epididymis. Cell Tissue Res, 349:717-731.

Bilinska B, Wiszniewska B, Kosiniak-Kamysz $\mathbf{K}$, Kotula-Balak M, Gancarczyk M, Hejmej A, Sadowska J, Marchlewicz M, Kolasa A, WendaRozewicka L. 2006. Hormonal status of male reproductive system: androgens and estrogens in the testis and epididymis. In vivo and in vitro approaches. Reprod Biol, 6(Suppl. 1):43-58.

Bjorkgren I, Saastamoinen L, Krutskikh A, Huhtaniemi I, Poutanen M, Sipila P. 2012. Dicer1 ablation in the mouse epididymis causes dedifferentiation of the epithelium and imbalance in sex steroid signaling. PloS one, 7:e38457.

Blomqvist SR, Vidarsson H, Soder O, Enerback S. 2006. Epididymal expression of the forkhead transcription factor Foxi1 is required for male fertility. EMBOJ, 25:4131-4141.

Bork K, Chevrier C, Paquignon M, Jouannet P, Dacheux JL. 1988. [Flagellar motility amd movement of boar spermatozoa during epididymal transit]. Reprod Nutr Dev, 28:1307-1315.

Breton S, Ruan YC, Park YJ, Kim B. 2016 Regulation of epithelial function, differentiation, and remodeling in the epididymis. Asian J Androl, 18:3-9.

Brooks DE. 1976. Changes in the composition of the excurrent duct system of the rat testis during postnatal development. J Reprod Fertil, 46:31-38.

Cancel AM, Chapman DA, Killian GJ. 1997. Osteopontin Is the 55-Kilodalton Fertility-Associated Protein in Holstein Bull Seminal Plasma. Biol Reprod, 57:1293-1301.

Carlson AE, Hille B, Babcock DF. 2007. External $\mathrm{Ca} 2+$ acts upstream of adenylyl cyclase SACY in the bicarbonate signaled activation of sperm motility. Dev Biol, 312:183-192.

Carlson AE, Westenbroek RE, Quill T, Ren D, Clapham DE, Hille B, Garbers DL, Babcock DF. 2003. CatSper1 required for evoked $\mathrm{Ca} 2+$ entry and control of flagellar function in sperm. Proc Natl Acad Sci U S A, 100:14864-14868.

Castella S, Benedetti H, de Llorens R, Dacheux JL, Dacheux F. 2004. Train A, an RNase A-like protein without RNase activity, is secreted and reabsorbed by the same epididymal cells under testicular control. Biol Reprod, 71:1677-1687.

Chevrier C, Dacheux JL. 1992. Evolution of the flagellar waveform of ram spermatozoa in relation to the degree of epididymal maturation. Cell Motil Cytoskeleton, 23:8-18

Clulow J, Jones RC, Hansen LA. 1994.
Micropuncture and cannulation studies of fluid composition and transport in the ductuli efferentes testis of the rat: comparisons with the homologous metanephric proximal tubule. Exp Physiol, 79:915-928.

Cooper TG. 1998. Interactions between epididymal secretions and spermatozoa. J Reprod Fertil Suppl, 53:119-136.

Cooper TG, Barfield JP. 2006. Utility of infertile male models for contraception and conservation. Mol Cell Endocrinol, 250:206-211.

Cornwall GA. 2009. New insights into epididymal biology and function. Hum Reprod Update, 15:213-227.

Cornwall GA, Hsia N. 1997. ADAM7, a member of the ADAM (a disintegrin and metalloprotease) gene family is specifically expressed in the mouse anterior pituitary and epididymis. Endocrinology, 138:42624272.

D'Amours O, Frenette G, Bordeleau L-J, Allard N, Leclerc P, Blondin P, Sullivan R. 2012. Epididymosomes Transfer Epididymal Sperm Binding Protein 1 (ELSPBP1) to Dead Spermatozoa During Epididymal Transit in Bovine. Biol Reprod, 87:94, 9111.

Da Silva N, Barton CR. 2016. Macrophages and dendritic cells in the post-testicular environment. Cell Tissue Res, 363:97-104.

Da Silva N, Shum WW, Breton S. 2007a. Regulation of vacuolar proton pumping ATPase-dependent luminal acidification in the epididymis. Asian J Androl, 9:476482.

Da Silva N, Shum WW, El-Annan J, Paunescu TG, McKee M, Smith PJ, Brown D, Breton S. 2007b. Relocalization of the V-ATPase B2 subunit to the apical membrane of epididymal clear cells of mice deficient in the B1 subunit. American journal of physiology Cell physiology, 293:C199-210.

Dacheux JL, Belghazi M, Lanson Y, Dacheux F. 2006. Human epididymal secretome and proteome. Mol Cell Endocrinol, 250:36-42.

Dacheux JL, Belleannee C, Guyonnet B, Labas V, Teixeira-Gomes AP, Ecroyd H, Druart X, Gatti JL, Dacheux F. 2012. The contribution of proteomics to understanding epididymal maturation of mammalian spermatozoa. Syst Biol Reprod Med, 58:197-210.

Dacheux JL, Belleannee C, Jones R, Labas V, Belghazi M, Guyonnet B, Druart X, Gatti JL, Dacheux F. 2009. Mammalian epididymal proteome. Mol Cell Endocrinol, 306:45-50.

Dacheux JL, Castella S, Gatti JL, Dacheux F. 2005. Epididymal cell secretory activities and the role of proteins in boar sperm maturation. Theriogenology, 63:319-341.

Dacheux JL, Dacheux F. 2014. New insights into epididymal function in relation to sperm maturation. Reproduction, 147:R27-42.

Dacheux JL, Dacheux F, Paquignon M. 1989. Changes in sperm surface membrane and luminal protein fluid content during epididymal transit in the boar. Biol Reprod, 40:635-651.

Dacheux JL, Gatti JL, Dacheux F. 2003. Contribution of epididymal secretory proteins for spermatozoa maturation. Microsc Res Tech, 61:7-17. 
Dacheux JL, Paquignon M. 1980. Relations between the fertilizing ability, motility and metabolism of epididymal spermatozoa. Reprod Nutr Dev, 20:10851099.

Damm OS, Cooper TG. 2010. Maturation of sperm volume regulation in the rat epididymis. Asian J Androl, 12:578-590.

Danzo BJ, Cooper TG, Orgebin-Crist MC. 1977. Androgen binding protein (ABP) in fluids collected from the rete testis and cauda epididymidis of sexually mature and immature rabbits and observations on morphological changes in the epididymis following ligation of the ductuli efferentes. Biol Reprod, 17:64-77. Domeniconi RF, Souza AC, Xu B, Washington AM, Hinton BT. 2016. Is the Epididymis a Series of Organs Placed Side By Side? Biol Reprod, 95:10.

Ecroyd H, Asquith KL, Jones RC, Aitken RJ. 2004 The development of signal transduction pathways during epididymal maturation is calcium dependent. Dev Biol, 268:53-63.

Eickhoff R, Baldauf C, Koyro HW, Wennemuth G, Suga Y, Seitz J, Henkel R, Meinhardt A. 2004 Influence of macrophage migration inhibitory factor (MIF) on the zinc content and redox state of proteinbound sulphydryl groups in rat sperm: indications for a new role of MIF in sperm maturation. Mol Hum Reprod, 10:605-611.

Eickhoff R, Jennemann G, Hoffbauer G, Schuring MP, Kaltner H, Sinowatz F, Gabius HJ, Seitz J. 2006. Immunohistochemical detection of macrophage migration inhibitory factor in fetal and adult bovine epididymis: release by the apocrine secretion mode? Cells Tissues Organs, 182:22-31.

Eickhoff R, Wilhelm B, Renneberg H, Wennemuth G, Bacher M, Linder D, Bucala R, Seitz J, Meinhardt A. 2001. Purification and characterization of macrophage migration inhibitory factor as a secretory protein from rat epididymis: evidences for alternative release and transfer to spermatozoa. Mol Med, 7:27-35.

Ekhlasi-Hundrieser M, Schafer B, Philipp U, Kuiper H, Leeb T, Mehta M, Kirchhoff C, Topfer-Petersen E. 2007. Sperm-binding fibronectin type II-module proteins are genetically linked and functionally related. Gene, 392:253-265.

Esseltine JL, Scott JD. 2013. AKAP signaling complexes: pointing towards the next generation of therapeutic targets? Trends Pharmacol Sci, 34:648-655. Ezer N, Robaire B. 2003. Gene expression is differentially regulated in the epididymis after orchidectomy. Endocrinology, 144:975-988.

Fan X, Robaire B. 1998. Orchidectomy induces a wave of apoptotic cell death in the epididymis. Endocrinology, 139:2128-2136.

Fawcett DW, Hoffer AP. 1979. Failure of exogenous androgen to prevent regression of the initial segments of the rat epididymis after efferent duct ligation or orchidectomy. Biol Reprod, 20:162-181.

Fornes WM, Sosa MA, Bertini F, Burgos MH. 1995. Vesicles in rat epididymal fluid. Existence of two populations differing in ultrastructure and enzymatic composition. Andrologia, 27:233-237.

Fouchécourt S, Métayer S, Locatelli A, Dacheux F,
Dacheux J-L. 2000. Stallion Epididymal Fluid Proteome: Qualitative and Quantitative Characterization; Secretion and Dynamic Changes of Major Proteins. Biol Reprod, 62:1790-1803.

Fouchecourt S, Metayer S, Locatelli A, Dacheux F, Dacheux JL. 2000. Stallion epididymal fluid proteome: qualitative and quantitative characterization; secretion and dynamic changes of major proteins. Biol Reprod, 62:1790-1803

Fraile B, Martin R, De Miguel MP, Arenas MI, Bethencourt FR, Peinado F, Paniagua R, Santamaria L. 1996. Light and electron microscopic immunohistochemical localization of protein gene product 9.5 and ubiquitin immunoreactivities in the human epididymis and vas deferens. Biol Reprod, 55:291-297.

Frenette G, Lessard C, Madore E, Fortier MA, Sullivan R. 2003. Aldose reductase and macrophage migration inhibitory factor are associated with epididymosomes and spermatozoa in the bovine epididymis. Biol Reprod, 69:1586-1592.

Frenette G, Lessard C, Sullivan R. 2002. Selected proteins of "prostasome-like particles" from epididymal cauda fluid are transferred to epididymal caput spermatozoa in bull. Biol Reprod, 67:308-313.

Gatti JL, Castella S, Dacheux F, Ecroyd H, Metayer S, Thimon V, Dacheux JL. 2004. Post-testicular sperm environment and fertility. Anim Reprod Sci, 82-83:321339.

Gatti JL, Metayer S, Belghazi M, Dacheux F, Dacheux JL. 2005. Identification, proteomic profiling, and origin of ram epididymal fluid exosome-like vesicles. Biol Reprod, 72:1452-1465.

Girouard J, Frenette G, Sullivan R. 2011. Comparative proteome and lipid profiles of bovine epididymosomes collected in the intraluminal compartment of the caput and cauda epididymidis. Int $J$ Androl, 34:e475-486.

Guduric-Fuchs J, O'Connor A, Camp B, O'Neill CL, Medina RJ, Simpson DA. 2012. Selective extracellular vesicle-mediated export of an overlapping set of microRNAs from multiple cell types. BMC Genomics, 13:357.

Guyonnet B, Dacheux F, Dacheux JL, Gatti JL. 2011. The epididymal transcriptome and proteome provide some insights into new epididymal regulations. $J$ Androl, 32:651-664.

Hamzeh M, Robaire B. 2011. Androgens activate mitogen-activated protein kinase via epidermal growth factor receptor/insulin-like growth factor 1 receptor in the mouse PC-1 cell line. J Endocrinol, 209:55-64.

Hawkins SM, Buchold GM, Matzuk MM. 2011. Minireview: The roles of small RNA pathways in reproductive medicine. Mol Endocrinol, 25:1257-1279.

Heinlein CA, Chang C. 2002a. Androgen receptor (AR) coregulators: an overview. Endocr Rev, 23:175200.

Heinlein CA, Chang C. 2002b. The roles of androgen receptors and androgen-binding proteins in nongenomic androgen actions. Mol Endocrinol, 16:2181-2187.

Herak-Kramberger CM, Breton S, Brown D, Kraus O, Sabolic I. 2001. Distribution of the vacuolar H+ 
atpase along the rat and human male reproductive tract. Biol Reprod, 64:1699-1707.

Hermo L, Jacks D. 2002. Nature's ingenuity: bypassing the classical secretory route via apocrine secretion. Mol Reprod Dev, 63:394-410.

Hermo L, Xiaohong S, Morales CR. 2000. Circulating and luminal testicular factors affect LRP-2 and Apo J expression in the epididymis following efferent duct ligation. J Androl, 21:122-144.

Hess RA. 2002. The Efferent Ductules: Structure and Functions. In: Robaire B, Hinton BT (Eds.). The Epididymis: from Molecules to Clinical Practice. New York: Kluwer Academic/Plenum Publishers. pp.49-80.

Hess RA, Bunick D, Bahr J. 2001a. Oestrogen, its receptors and function in the male reproductive tract - a review. Mol Cell Endocrinol, 178:29-38.

Hess RA, Bunick D, Bahr JM. 1995. Sperm, a source of estrogen. Environ Health Perspect, 103(Suppl 7):5962.

Hess RA, Zhou Q, Nie R, Oliveira C, Cho H, Nakaia M, Carnes K. 2001b. Estrogens and epididymal function. Reprod Fertil Dev, 13:273-283.

Hinton BT, Galdamez MM, Sutherland A, Bomgardner D, Xu B, Abdel-Fattah R, Yang L. 2011. How do you get six meters of epididymis inside a human scrotum? J Androl, 32:558-564.

Hinton BT, Lan ZJ, Rudolph DB, Labus JC, Lye RJ. 1998. Testicular regulation of epididymal gene expression. J Reprod Fertil Suppl, 53:47-57.

Holland MK, Vreeburg JT, Orgebin-Crist MC. 1992. Testicular regulation of epididymal protein secretion. J Androl, 13:266-273.

Hoskins DD, Stephens DT, Hall ML. 1974. Cyclic adenosine 3':5'-monophosphate and protein kinase levels in developing bovine spermatozoa. $J$ Reprod Fertil, 37:131-133.

Inskeep PB, Hammerstedt RH. 1982. Changes in metabolism of ram sperm associated with epididymal transit or induced by exogenous carnitine. Biol Reprod, 27:735-743.

Janne OA, Moilanen AM, Poukka H, Rouleau N, Karvonen U, Kotaja N, Hakli M, Palvimo JJ. 2000. Androgen-receptor-interacting nuclear proteins. Biochem Soc Trans, 28:401-405.

Jones RC, Dacheux JL, Nixon B, Ecroyd HW. 2007. Role of the epididymis in sperm competition. Asian $J$ Androl, 9:493-499.

Joseph A, Shur BD, Hess RA. 2011. Estrogen, efferent ductules, and the epididymis. Biol Reprod, 84:207-217.

Kempinas WG, Klinefelter GR. 2014. Interpreting histopathology in the epididymis. Spermatogenesis, 4:e979114.

Kirchhoff C, Osterhoff C, Young L. 1996. Molecular cloning and characterization of HE1, a major secretory protein of the human epididymis. Biol Reprod, 54:847856.

Krege JH, John SW, Langenbach LL, Hodgin JB, Hagaman JR, Bachman ES, Jennette JC, O'Brien DA, Smithies O. 1995. Male-female differences in fertility and blood pressure in ACE-deficient mice. Nature, 375:146-148.

Lan ZJ, Labus JC, Hinton BT. 1998. Regulation of gamma-glutamyl transpeptidase catalytic activity and protein level in the initial segment of the rat epididymis by testicular factors: role of basic fibroblast growth factor. Biol Reprod, 58:197-206.

Legare C, Gaudreault C, St-Jacques S, Sullivan R. 1999. P34H sperm protein is preferentially expressed by the human corpus epididymidis. Endocrinology, 140:3318-3327.

Lindemann CB, Gardner TK, Westbrook E, Kanous KS. 1991. The calcium-induced curvature reversal of rat sperm is potentiated by cAMP and inhibited by anticalmodulin. Cell Motil Cytoskeleton, 20:316-324.

Manjunath P, Bergeron A, Lefebvre J, Fan J. 2007. Seminal plasma proteins: functions and interaction with protective agents during semen preservation. Society of Reproduction and Fertility Supplement, 65:217-228.

Manjunath P, Thérien I. 2002. Role of seminal plasma phospholipid-binding proteins in sperm membrane lipid modification that occurs during capacitation $J$ Reprod Immunol, 53:109-119

Mittelbrunn M, Gutierrez-Vazquez C, VillarroyaBeltri C, Gonzalez S, Sanchez-Cabo F, Gonzalez MA, Bernad A, Sanchez-Madrid F. 2011. Unidirectional transfer of microRNA-loaded exosomes from $\mathrm{T}$ cells to antigen-presenting cells. Nature communications, 2:282.

Moura AA, Souza CE, Stanley BA, Chapman DA, Killian GJ. 2010. Proteomics of cauda epididymal fluid from mature Holstein bulls. Journal of proteomics, 73:2006-2020

Nicander L, Osman DI, Ploen L, Bugge HP, Kvisgaard KN. 1983. Early effects of efferent ductule ligation on the proximal segment of the rat epididymis. Int J Androl, 6:91-102.

Nixon B, Ecroyd HW, Dacheux JL, Jones RC. 2011. Monotremes provide a key to understanding the evolutionary significance of epididymal sperm maturation. J Androl, 32:665-671.

Palladino MA, Hinton BT. 1994a. Developmental regulation of expression of multiple gamma-glutamyl transpeptidase mRNAs in the postnatal rat epididymis. Biochem Biophys Res Commun, 198:554-559.

Palladino MA, Hinton BT. 1994b. Expression of multiple gamma-glutamyl transpeptidase messenger ribonucleic acid transcripts in the adult rat epididymis is differentially regulated by androgens and testicular factors in a region-specific manner. Endocrinology, 135:1146-1156.

Papaioannou MD, Nef S. 2010. microRNAs in the testis: building up male fertility. $J$ Androl, 31:26-33.

Pariset CC, Feinberg JM, Dacheux JL, Weinman SJ. 1985. Changes in calmodulin level and cAMPdependent protein kinase activity during epididymal maturation of ram spermatozoa. $J$ Reprod Fertil, 74:105-112.

Pastor-Soler N, Beaulieu V, Litvin TN, Da Silva N, Chen Y, Brown D, Buck J, Levin LR, Breton S. 2003. Bicarbonate-regulated adenylyl cyclase (sAC) is a sensor that regulates $\mathrm{pH}$-dependent V-ATPase recycling. J Biol Chem, 278:49523-49529.

Pastor-Soler NM, Hallows KR, Smolak C, Gong F, Brown D, Breton S. 2008. Alkaline pH- and cAMP- 
induced V-ATPase membrane accumulation is mediated by protein kinase A in epididymal clear cells. American journal of physiology Cell physiology, 294:C488-494.

Payan-Carreira R, Borges $P$, Mir F, Fontbonne A.2013. Molecular Markers in Sperm Analysis. In: Lemma A (Eds.). Success in Artificial Insemination Quality of Semen and Diagnostics Employed: InTech.

Perino A, Ghigo A, Scott JD, Hirsch E. 2012. Anchoring proteins as regulators of signaling pathways. Circ Res, 111:482-492.

Rejraji H, Sion B, Prensier G, Carreras M, Motta C, Frenoux JM, Vericel E, Grizard G, Vernet P, Drevet JR. 2006. Lipid remodeling of murine epididymosomes and spermatozoa during epididymal maturation. Biol Reprod,74:1104-1113.

Rejraji H, Vernet P, Drevet JR. 2002. GPX5 is present in the mouse caput and cauda epididymidis lumen at three different locations. Mol Reprod Dev, 63:96-103.

Rigaudiere N, Ghyselinck NB, Faure J, Dufaure JP. 1992. Regulation of the epididymal glutathione peroxidase-like protein in the mouse: dependence upon androgens and testicular factors. Mol Cell Endocrinol, 89:67-77.

Robaire B, Hamzeh M. 2011. Androgen action in the epididymis. J Androl, 32:592-599.

Robaire B, Hinton BT, Orgebin-Crist M-C, Jimmy DN, Ph.D, Tony MP, Ph.D, Donald WP, Ph.D, John RGC, D.Sc, F.R.S.C, David MdK, M.D, A.O, JoAnne SR, Ph.D, Paul MW, Ph.D.2006. The EpididymisKnobil and Neill's Physiology of Reproduction (Third Edition). St Louis: Academic Press. pp.1071-1148.

Saez F, Ouvrier A, Drevet JR. 2011. Epididymis cholesterol homeostasis and sperm fertilizing ability. Asian J Androl, 13:11-17.

Schorr-Lenz AM, Alves J, Henckes NA, Seibel PM, Benham AM, Bustamante-Filho IC. 2016. GnRH immunization alters the expression and distribution of protein disulfide isomerases in the epididymis. Andrology, 4(5):957-963.

Schwarz A, Wennemuth G, Post H, Brandenburger T, Aumuller G, Wilhelm B. 2013. Vesicular transfer of membrane components to bovine epididymal spermatozoa. Cell Tissue Res, 353:549-561.

Shum WW, Da Silva N, McKee M, Smith PJ, Brown D, Breton S. 2008. Transepithelial projections from basal cells are luminal sensors in pseudostratified epithelia. Cell, 135:1108-1117.

Shum WW, Ruan YC, Da Silva N, Breton S. 2011. Establishment of cell-cell cross talk in the epididymis: control of luminal acidification. $J$ Androl, 32:576-586.

Shum WW, Smith TB, Cortez-Retamozo V, Grigoryeva LS, Roy JW, Hill E, Pittet MJ, Breton S, Da Silva N. 2014. Epithelial basal cells are distinct from dendritic cells and macrophages in the mouse epididymis. Biol Reprod, 90:90.

Sostaric E, Aalberts M, Gadella BM, Stout TA. 2008. The roles of the epididymis and prostasomes in the attainment of fertilizing capacity by stallion sperm. Anim Reprod Sci, 107:237-248.

Souza CE, Rego JP, Lobo CH, Oliveira JT, Nogueira
FC, Domont GB, Fioramonte M, Gozzo FC, Moreno FB, Monteiro-Moreira AC, Figueiredo JR, Moura AA. 2012. Proteomic analysis of the reproductive tract fluids from tropically-adapted Santa Ines rams. Journal of proteomics, 75:4436-4456.

Sullivan R, Frenette G, Girouard J. 2007. Epididymosomes are involved in the acquisition of new sperm proteins during epididymal transit. Asian $J$ Androl, 9:483-491.

Sullivan R, Saez F. 2013. Epididymosomes, prostasomes, and liposomes: their roles in mammalian male reproductive physiology. Reproduction, 146:R2135 .

Sullivan R, Saez F, Girouard J, Frenette G. 2005. Role of exosomes in sperm maturation during the transit along the male reproductive tract. Blood Cells Mol Dis, $35: 1-10$

Sutovsky P. 2015. New Approaches to Boar Semen Evaluation, Processing and Improvement. Reprod Domest Anim, 50(Suppl.2):11-19.

Sutovsky P, Moreno R, Ramalho-Santos J, Dominko T, Thompson WE, Schatten G. 2001. A putative, ubiquitin-dependent mechanism for the recognition and elimination of defective spermatozoa in the mammalian epididymis. J Cell Sci, 114:1665-1675.

Syntin P, Dacheux F, Druart X, Gatti JL, Okamura N, Dacheux JL. 1996. Characterization and identification of proteins secreted in the various regions of the adult boar epididymis. Biol Reprod, 55:956-974.

Syntin P, Dacheux J-L, Dacheux F. 1999. Postnatal Development and Regulation of Proteins Secreted in the Boar Epididymis. Biol Reprod, 61:1622-1635.

Thimon V, Calvo E, Koukoui O, Legare C, Sullivan R. 2008a. Effects of vasectomy on gene expression profiling along the human epididymis. Biol Reprod, 79:262-273.

Thimon V, Frenette G, Saez F, Thabet M, Sullivan R. 2008b. Protein composition of human epididymosomes collected during surgical vasectomy reversal: a proteomic and genomic approach. Hum Reprod, 23:1698-1707.

Turner RM. 2006. Moving to the beat: a review of mammalian sperm motility regulation. Reprod Fertil Dev, 18:25-38.

Turner TT, Bomgardner D, Jacobs JP, Nguyen QA. 2003. Association of segmentation of the epididymal interstitium with segmented tubule function in rats and mice. Reproduction, 125:871-878.

Turner TT, Johnston DS, Finger JN, Jelinsky SA. 2007a. Differential gene expression among the proximal segments of the rat epididymis is lost after efferent duct ligation. Biol Reprod, 77:165-171.

Turner TT, Johnston DS, Jelinsky SA, Tomsig JL, Finger JN. 2007b. Segment boundaries of the adult rat epididymis limit interstitial signaling by potential paracrine factors and segments lose differential gene expression after efferent duct ligation. Asian J Androl, 9:565-573.

Veeramachaneni DN, Amann RP. 1991. Endocytosis of androgen-binding protein, clusterin, and transferrin in the efferent ducts and epididymis of the ram. J Androl, 12:288-294. 
Vernet P, Faure J, Dufaure JP, Drevet JR. 1997. Tissue and developmental distribution, dependence upon testicular factors and attachment to spermatozoa of GPX5, a murine epididymis-specific glutathione peroxidase. Mol Reprod Dev, 47:87-98.

Vidarsson H, Westergren R, Heglind M, Blomqvist SR, Breton S, Enerback S. 2009. The forkhead transcription factor Foxil is a master regulator of vacuolar H-ATPase proton pump subunits in the inner ear, kidney and epididymis. PloS one, 4:e4471.

Viger RS, Robaire B. 1996. The mRNAs for the steroid 5 alpha-reductase isozymes, types 1 and 2, are differentially regulated in the rat epididymis. $J$ Androl, 17:27-34.

Voglmayr JK, Sawyer RF, Jr., Dacheux JL. 1985. Glycoproteins: a variable factor in surface transformation of ram spermatozoa during epididymal transit. Biol Reprod, 33:165-176.

Wang G, Guo Y, Zhou T, Shi X, Yu J, Yang Y, et al. 2013. In-depth proteomic analysis of the human sperm reveals complex protein compositions. Journal of proteomics, 79:114-122.

Xia J, Reigada D, Mitchell CH, Ren D. 2007. CATSPER channel-mediated $\mathrm{Ca} 2+$ entry into mouse sperm triggers a tail-to-head propagation. Biol Reprod, 77:551-559.

Yeung CH, Breton S, Setiawan I, Xu Y, Lang F, Cooper TG. 2004. Increased luminal $\mathrm{pH}$ in the epididymis of infertile c-ros knockout mice and the expression of sodium-hydrogen exchangers and vacuolar proton pump H+-ATPase. Mol Reprod Dev, 68:159-168. 